\title{
OTORITAS PEMERINTAH DALAM PENETAPAN AWAL BULAN QAMARIYAH PERSPEKTIF FIQH SIYÂSAH YUSUF QARDHAWI.
}

\author{
M. Nur Hidayat \\ Fakultas Syariah UIN Maulana Malik Ibrahim Malang \\ E-mail:hiday4t_78@yahoo.co.id
}

\begin{abstract}
Abstrak
The disparity of determining the early month of Qamariyah in Indonesia is a common phenomenon every year. Therefore, the government, through Ministry of Religious Affairs tries to find a solution for the problem. The focus of this study is to discuss the government's authority in determining the early month of Qamariyah based on Yusuf Qardhawi's Political Figh Perspective. As a result, the study shows that the government, the Ministry of Religious Affairs of Indonesia, has an authority in determining the early month of Qamariyah. Meanwhile, Islamic organizations or other mass organizations have no authority at all. But, they deserve in announcing after receiving the information from government. Furthermore, the government's decision is considered as an obligation which has to be obeyed for those having no ability in determining the early month of Qamariyah (independent-ijtihad).

Perbedaan penetapan awal bulan Qamariyah di Indonesia menjadi sebuah fenomena dalam setiap tahun. Guna menjembatani perbedaan tersebut, pemerintah mengambil langkah solutif untuk menyelesaikan permasalahan tersebut. Fokus penelitian ini adalah untuk mendiskusikan otoritas pemerintah dalam penetapan awal bulan Qamariyah perspektif fiqh siyâsah Yusuf Qardhawi. Dari hasil penelitian, diperoleh kesimpulan bahwa pemerintah dalam hal ini Kementerian Agama RI mempunyai otoritas dalam menetapkan (itsbât) awal bulan Qamariyah. Sedangkan organisasi ataupun ormas Islam di luar pemerintah pada hakikatnya tidak mempunyai otoritas dalam menetapkan awal bulan Qamariyah, akan tetapi hanya sekedar mengumumkan (ikhbâr) terkait dengan awal bulan qamariyah. Selanjutnya mengenai keputusan pemerintah, pada dasarnya wajib diikuti bagi mereka yang tidak mempunyai kemampuan untuk melakukan ijtihad sendiri dalam menentukan awal bulan Qamariyah.
\end{abstract}

Kata kunci: Awal Bulan Qamariyah, Pemerintah, Fiqh Siyâsah

Penetuan awal bulan Qamariyah penting artinya bagi umat Islam. Hal ini karena selain untuk menentukan hari-hari besar, penentuan awal bulan juga penting untuk menentukan awal bulan Ramadhan, Syawal dan Dzulhijjah. Persoalan tersebut menyangkut "wajib 'ain" bagi setiap umat Islam dalam menunaikan ibadah puasa Ramadhan, membayar zakat fitrah serta ibadah haji. Persoalan penetapan awal bulan Qamariyah tidak seperti halnya penentuan waktu shalat dan arah qiblat, yang tampaknya setiap orang sepakat terhadap hasil hisab. Namun penentuan awal bulan ini menjadi persoalan yang diperselisihkan tentang "metode" yang dipergunakannya. ${ }^{1}$

\footnotetext{
Departemen Agama RI, Alamanak Hisab Rukyat, (Jakarta: Proyek Pembinaan Badan Peradilan Agama Islam, 1981), h. 18
}

Di Indonesia, tercatat beberapa kali perbedaan penetapan awal bulan Qamariyah. Di antaranya pada tahun 1997, 1998, 2007 dan pada tahun 2011. ${ }^{2}$ Salah satu penyebab terjadinya perbedaan tersebut, disebabkan adanya perbedaan metode yang dipergunakan. Di kalangan ulama ahli falak, ada dua metode yang mashur dipergunakan. Di antaranya metode hisab dan rukyat. ${ }^{3}$ Perbedaan tersebut agaknya menimbulkan psikis umat Islam menjadi tidak sehat. Masyarakat akhirnya terombang-ambing, kapan harus mengakhiri atau meneruskan puasanya. Belum lagi masyarakat harus mempersiapkan segala kebutuhan

\footnotetext{
2 Hari Idul Fitri Bisa Berbeda, Kompas, 26 Agustus 2011. Baca juga di http://nasional.kompas.com/read/2011/08/26/2124008/Hari.Idul.Fitri.Bisa. Berbeda. Diakses pada tanggal 16 November 2011

3 Murtadho, Imkân al-Rukyat Dalam Penentuan awal Bulan Qamariyah: Perspektif Syariah dan Astronomi Manhaj Nahdlatul Ulama, El-Qisth Jurnal Hukum, (2007), h. 293-294
} 
terkait dengan persiapan pelaksanaan sholat Idul Fitri ataupun mengeluarkan dan membagikan zakat. Bahkan lebih ekstrim lagi, perbedaan tersebut disinyalir karena terjadi perbedaan pandangan politik. ${ }^{4}$ Dengan demikian, masyarakat selalu melihat adanya perbedaan ketimbang persatuan dan kesatuan yang indah.

Adanya sikap saling menghargai dan toleransi yang dimiliki umat Islam atas adanya perbedaan penetapan awal bulan Qamariyah, sangatlah diperlukan dan perlu digalakkan. Akan tetapi, sikap tersebut harus diikuti oleh ikhtiar konkrit untuk melakukan upaya taqrîb (pendekatan) menuju kesatuan dan penyatuan umat. Masalah penetapan awal bulan, dimungkinkan akan terjadinya perbedaan akibat (salah satunya) perbedaan metode yang digunakan. Namun persoalan tersebut termasuk dalam kategori fiqh ijtima'i (ketentuan fikih yang memiliki dimensi sosial), sehingga membutuhkan pengaturan ulîl amri untuk kepentingan ketertiban. ${ }^{5}$

Maka dari itu, dalam hal penetapan awal bulan, campur tangan ulîl amri sangatlah menentukan peranan yang sangat signifikan. Di Indonesia, peranan ulîl amri pada dasarnya sudah teraplikasikan melalui Kementerian Agama Republik Indonesia. Kementerian Agama dalam hal ini bertindak sebagai representasi pemerintah dalam menetapkan awal bulan. Namun realita di lapangan, keputusan yang telah dikeluarkan oleh pemerintah (Kementerian Agama) tidak sepenuhnya bulat dilaksanakan oleh semua golongan masyarakat. Padahal dalam kepanitiaannya melibatkan seluruh ormas-ormas besar Islam, seperti Muhammadiyah, Nahdlatul Ulama, Persis, dan lembaga-lembaga ilmiah seperti Lembaga Antariksa Dan Penerbangan Nasional (LAPAN) dan Observatorium Boscha. ${ }^{6}$ Padahal dalam al-Qur'an telah dijelaskan sebagaimana berikut:

"Hai orang-orang yang beriman, taatilah Allah dan taatilah Rasul (Nya), dan ulîl amri di antara kamu. kemudian jika kamu berlainan Pendapat tentang sesuatu, Maka kembalikanlah ia kepada Allah (Al Quran) dan Rasul (sunnahnya), jika kamu benarbenar beriman kepada Allah dan hari kemudian. yang demikian itu lebih utama (bagimu) dan lebih baik akibatnya." (QS: al-Nisa' (04): 59)

\footnotetext{
4 http://www.detiknews.com/read/2011/08/30/101326/1713447/103/bedasikap-politik-beda-hari-raya, Diakses pada tanggal 16 November 2011

5 Asrorun Ni'am, "Idul Fitri Mazhab Negara", http://www.mui.or.id/index. php?option $=$ com content\&view $=$ article $\&$ id $=541$ :idul-fitri-madzhabnegara\&catid $=35:$ materi-artikel\&Itemid $=56$, diakses pada tanggal 16 November 2011

6 Asrorun Ni'am, “Idul Fitri,
}

Dengan memperhatikan kandungan hukum dari ayat tersebut. Bahwa pemerintah dalam hal perintahnya wajib dipatuhi dan dilaksanakan, sebatas perintah tersebut tidak menyuruh kepada kemungkaran. Nampaknya ayat tersebut dijustifikasi dengan kaidah fikih yang berbunyi:

"Keputusan pemerintah itu mengikat (wajib dipatuhi) dan menghilangkan silang pendapat."

Dengan demikian, berpijak dari ayat al-Qur'an dan kaidah fikih di atas, masalah-masalah keagamaan yang mempunyai relasi dengan urusan sosial kemasyarakatan, pemerintah berhak ikut campur dan memutuskan. Keputusan tersebut pada dasarnya bersifat memaksa (binding/ilzâm).

Namun persoalannya, sistem pemerintahan di Indonesia bukanlah sistem pemerintahan Islam sebagaimana dipraktekkan Nabi pada zaman dahulu. Bagaimana jika pemerintah tersebut mengeluarkan perintah atau kebijakan terkait dengan permasalahan agama? Apakah perintah tersebut harus dipatuhi sebagaimana dahulu?

Persoalan aktual ini akan menarik jika dikaji dengan fiqh Siyâsah, yang tujuan dari fikih tersebut adalah kemaslahatan umat. Dalam pergumulan pembahasan fiqh Siyâsah, ada banyak ulama klasik dan kontemporer yang fokus dalam pembahasan tersebut. Namun dari beberapa ulama-ulama, penulis memilih untuk mengupas lebih jauh dengan menggunakan fiqh Siyâsah perspektif Yusuf Qardhawi. Alasan yang mendasari penulis adalah, Yusuf Qardhawi merupakan seorang ulama kontemporer yang hidup pada zaman sekarang dan faham terhadap sistemsistem pemerintahan modern, seperti demokrasi yang sekarang dianut oleh Indonesia. Di samping itu, Qardhawi juga mempunyai konsep negara Islam yang detail dibandingkan dengan ulama-ulama yang lain. Berangkat dari permasalah inilah, peneliti bermaskud mengadakan penelitian lebih jauh terkait dengan penetapan awal bulan Qamariyah oleh pemerintah.

\section{Pengertian Awal Bulan Qamariyah}

Sebagaimana diketahui bahwa perjalanan waktu di bumi ini ditandai dengan peredaran benda-benda langit, terutama matahari dan bulan. Hal ini sebagaimana dijelaskan oleh Allah SWT dalam firman-Nya yang berbunyi:

"Dia-lah yang menjadikan matahari bersinar dan bulan bercahaya dan ditetapkan-Nya manzilahmanzilah (tempat-tempat) bagi perjalanan bulan itu, supaya kamu mengetahui bilangan tahun dan 
perhitungan (waktu). Allah tidak menciptakan yang demikian itu melainkan dengan hak. Dia menjelaskan tanda-tanda (kebesaran-Nya) kepada orang-orang yang mengetahui. (QS: Yunus (10): 5)."

Benda-benda langit yang dianggap paling penting menurut ahli falak adalah bulan, matahari dan bumi. Selanjutnya dari ayat tersebut, ulama-ulama falak menjadikan peredaran bulan mengelilingi bumi menjadi kaidah penyusunan bulan qamariyah, sedangkan peredaran bumi mengelilingi matahari menjadi penentuan bulan syamsiyah dan waktu-

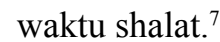

Secara garis besar, ada dua macam sistem penanggalan. Yakni sistem penanggalan yang didasarkan pada peredaran bumi menggelilingi matahari yang dikenal dengan sistem syamsiyah atau tahun surya dan yang didasarkan pada peredaran bulan mengelilingi bumi yang dikenal dengan sistem qamariyah atau lunar system. ${ }^{8}$

Dalam kalender Islam, hari dihitung sejak matahari terbenam, awal bulan Qamariyah dihitung sejak ijtima' atau terjadi penampakan hilâl. Periode dari ijtima' ke ijtima' berikutnya tersebut sebagai periode bulan sinodis (syahr iqtironi). Masa antara dua ijtima' inilah yang sering disebut sebagai usia bulan yang hakiki.

Dari uraian di atas, kemudian muncul paradigma awal bulan Qamariyah berdasarkan persepsi yang berbeda-beda. Awal bulan Qamariyah menurut ahli hisab adalah adanya hilal di atas ufuk pada saat matahari terbenam sedangkan ahli rukyat memberi ketentuan adanya hilal di atas ufuk pada waktu matahari terbenam dan dapat di rukyat. Adapun pakar astronomi menyatakan bahwa awal bulan terjadi sejak terjadinya konjungsi (ijtima' al-hilâl) segaris antara matahari dan bulan. ${ }^{9}$

\section{Metode Dan Mekanisme Penetapan Awal Bulan Qamariyah Pemerintah}

Dalam rangka memberikan jalan tengah (problem solving) dalam permasalahan awal bulan Qamariyah di Indonesia, yang sampai sekarang ini masih terjadi perdebatan antar ormas Islam yang belum diketahui kapan berakhirnya, pemerintah memberikan sebuah tawaran metode penetapan awal bulan yang disebut dengan Imkân Al-Rukyah. Secara

\footnotetext{
7 Murtadho, Ilmu Falak Praktis, (Malang: UIN Press, 2008), h. 216

8 Proyek Pembinaan Administrasi Hukum Dan Peradilan Agama, Pedoman Awal Bulan Qamariyah, (Jakarta: Proyek Pembinaan Administrasi Hukum dan Peradilan, 1983), h. 1

9 Murtadho, Ilmu, h. 220
}

harfiah, Imkân Al-Rukyah berarti kemungkinan hilâl terlihat. Sedangkan dalam bahasa Inggris biasanya diistilahkan dengan visibilitas hilal.

Selain memperhitungkan wujudnya hilal di atas ufuk, pelaku hisab juga memperhitungkan faktorfaktor lain yang memungkinkan terlihatnya hilal. Faktor yang menentukan terlihatnya hilal bukan hanya keberadaanya di atas ufuk, melainkan ketinggian dan posisinya yang cukup jauh dari arah matahari. Kriteria itu didasarkan pada hasil rukyat jangka panjang yang dihitung secara hisab, sehingga dua pendapat hisab dan rukyat dapat terakomodasi. Kriteria itu digunakan untuk menghindari rukyat yang meragukan dan digunakan untuk penentuan awal bulan berdasarkan hisab. Dengan demikian diharapkan hasil hisab dan rukyat akan selalu seragam. ${ }^{10}$

Kriteria Imkân al-Rukyah, merupakan kriteria dalam penentuan awal bulan Qomariyah, yang posisinya menjembatani antara kriteria Rukyah al-Hilâl dan kriteria Wujud al-Hilâl. Kriteria ini banyak dipergunakan oleh pemerintah-pemerintah di ASEAN dalam menentukan awal bulan Qomariyah. Kemudian muncul dalam penanggalan hijriyah standard empat negara ASEAN, kriteria ini ditetapkan berdasarkan musyawarah menteri-menteri Agama Brunei Darussalam, Indonesia, Malaysia, dan Singapura (MABINS).

Menurut musyawarah tersebut, Awal bulan terjadi jika: Pertama, Pada saat matahari terbenam, ketinggian (altitude) hilal di atas cakrawala minimum $2^{\circ}$, dan sudut elongasi (jarak lengkung) hilal dan Matahari minimum $3^{\circ}$. Ketinggian $2^{\circ}$ ini merupakan Kriteria yang dibuat berdasarkan pengalamanan rukyatul hilal di Indonesia selama puluhan tahun, walau pun secara internasional sangat diragukan posisi $2^{\circ}$ hilal bisa di lihat karena masih terlalu rendah. Kedua, Pada saat matahari terbenam, usia hilal lebih 8 jam dihitung sejak ijtimak, sehingga cahaya hilal telah mencapai standar hilal kemungkinan bisa dilihat. ${ }^{11}$

Sebelum diadakanya sidang itsbât awal bulan Qamariyah, terlebih dahulu pemerintah melakukan kegiatan rukyah al-hilâl (pengamatan bulan). Adapun secara teknis, pelaksanaan kegiatan tersebut dilakukan oleh Kementerian Agama daerah yang dijadikan tempat untuk pelaksanaan rukyat al-hilâl. Secara garis besar, di antara beberapa persiapan yang dilakukan oleh Kementerian Agama daerah sebagaimana di bawah ini: (1) Kementerian Agama pusat,

\footnotetext{
10 Thomas Djamaludin, Astronomi Memberi Solusi Penyatuan Umat, (Lembaga Penerbangan dan Antariksa Nasional: 2001), h. 11

11 Thomas, Astronomi, h. 18
} 
menginstruksikan kepada Kementerian Agama kabupaten (untuk daerah yang akan dijadikan tempat pelaksanaan rukyat) untuk berkoordinasi badan Hisab Dan Rukyat dan Pengadilan Agama setempat tentang persiapan kegiatan rukyat awal bulan hijriyah. (Biasanya untuk awal bulan Ramadhan, Syawal dan Dzulhijjah); (2) Kepala Kantor Kementrian Agama daerah setempat selaku koordinator acara kegiatan rukyat berkirim surat kepada Ketua Pengadilan Agama setempat agar menunjuk seorang Hakim dan Panitera sidang untuk melakukan sidang isbat kesaksian rukyat bila hilal berhasil dirukyat oleh orang perukyat. (3) Setelah itu, Kepala Kantor Kementerian Agama daerah tersebut mengirimkan surat kepada beberapa ormas Islam dan para perukyat agar hadir pada acara rukyat yang telah ditetapkan. (4) Pada hari pelaksanaan rukyat, dilaksanakan pada jam yang telah disepakati. Bila hilal berhasil dirukyat oleh perukyat, perukyat melapor kepada Koordinator/Kepala Kantor Kementrian Agama setempat. Kemudian, Kementrian Agama memohon kepada Hakim Pengadilan Agama agar segera diadakan persidangan untuk memeriksa dan menetapkan kesaksian hilal. (5) Hasil rukyat, baik hilal yang berhasil dilihat, maupun tidak, dilaporkan kepada Kementrian Agama RI/BHR Pusat sebagai bahan pertimbangan Menteri Agama RI dalam menetapkan awal Bulan yang bersangkutan. ${ }^{12}$

Setelah hasil dilaporkan kepada Kementerian Agama RI (pusat) dari beberapa lokasi-lokasi pelaksanaan rukyat di seluruh Indonesia. Maka setelah itu, Kementerian Agama mengadakan sidang itsbât. Hadir dalam sidang tersebut beberapa perwakilan ormas Islam seperti Nahdlatul Ulama, Muhammadiyah, Persis dan lain sebagainnya. Begitu juga melibatkan dari tim Badan Hisab dan Rukyat (BHR) di antaranya, Observatorium Bosscha ITB, Planetarium Jakarta, Badan Meteorologi, Klimatologi, dan Geofisika (BMKG), serta Badan Koordinasi Survei dan Pemetaan Nasional (Bakosurtanal). ${ }^{13}$

Rapat sidang penetapan awal bulan diawali dengan pemaparan tentang prakiraan cuaca dan hal ihwal tentang hilal dari tim ahli seperti dari BMKG, LAPAN dan Observatorium Bosscha ITB. Kemudian disambung presentasi hasil observasi hilal. Setelah dipotong dengan buka puasa dan sholat maghrib, sidang kembali dilanjutkan. Setelah mendengar pre-

\footnotetext{
12 Ahmad Sanusi, Tata Laksana Kegiatan Rukyat Hilal Awal Bulan Hijriyah Di Pob Palabuhanratu, http://www.pa-cibadak.go.id/artikel/baca/17, diakses pada tanggal 26 Februari 2012.

13 Sidang Isbat penetapan 1 syawal pada 29 Agustus 2011, http://humassambas. com/info-humas/sidang-itsbat-penetapan-1-syawal-1432-pada-29-agustus2011/ diakses pada tanggal 26 Februari 2012.
}

sentasi hasil observasi hilal, Kementerian Agama mempersilahkan kepada para peserta untuk memberi masukan dan penjelasan mengenai hasil pengamatan hilal. Setelah dianggap cukup, ketua majelis sidang memberikan kesimpulan, setelah mengolah beberapa pertimbangan dan masukan mengenai hasil rapat kemudian membacakan kembali hasil rapat kepada para peserta.

Setelah itu menawarkan hasil tersebut untuk dimintakan kesepakatan kepada peserta sidang. Hasil suara mayoritas dari peserta sidang kemudian diambil sebagai pertimbangan. Ketua Majelis selanjutnya menetapkan dengan pertimbangan suara mayoritas tersebut. Sehingga menjadi sebuah ketetapan hasil dari sidang istbat pemerintah dalam penetapan awal bulan Qamariyah.

\section{Fiqh Siyâsah}

Topik bahasan ini terdiri dari dua kata yaitu, kata fiqh dan siyâsah. Agar diperoleh pemahaman yang komprehensif mengenai pengertian fiqh Siyâsah, maka perlu dijelaskan terlebih dahulu masing-masing dari istilah tersebut. Secara terminologis, menurut ulama-ulama syara', fiqh adalah pengetahuan tentang hukum-hukum yang sesuai dengan syara' mengenai amal perbuatan yang diperoleh dari dalil-dalil yang tafshil. ${ }^{14}$ Sedangkan kata al-Siyâsah berasal dari kata sasa-yasûsu-siyâsatan yang artinya mengatur, mengendalikan, memengurus atau membuat keputusan. ${ }^{15}$ Sedangkan pengertian siyâsah adalah: "Penguasaan kemaslahatan umat manusia dengan syara'.,

Adapun pengertian fiqh siyâsah adalah ilmu yang mempelajari hal-ihwal dan seluk beluk pengaturan pengaturan urusan umat dan negara dengan segala bentuk hukum, peraturan dan kebijaksanaan yang dibuat oleh pemegang kekuasaan yang sejalan dengan dasar-dasar ajaran dan ruh syariat untuk mewujudkan kemaslahatan umat. ${ }^{16}$ Dalam pengertian populernya, adalah ilmu tata negara dalam ilmu agama Islam yang dikategorikan kedalam pranata sosial Islam.

\section{Biografi Yusuf Qardhawi}

Nama lengkap dari Yusuf Qardhawi adalah Yusuf Abdullah al-Qardhawi, dilahirkan pada tahun 1926 M di desa Shafth Turab, provinsi Gharbiyah,

\footnotetext{
14 Muhammad Abu Zahrah, Ushul al-Figh, (Mishr: Dar al-Fikr, 1958), h. 6 15 Ahmad Djazuli, Fiqh Siyâsah (Implementasi Kemaslahatan Umat dalam Rambu-rambu Syariah), (Jakarta: Kencana, 2003), 25 lihat Suyuthi Pulungan, Fiqh Siyâsah Ajaran, Sejarah Dan Pemikiran, (Jakarta: PT Raja Grafindo, 1993), h. 22

16 Suyuthi Pulungan, Fiqh Siyâsah Ajaran, Sejarah Dan Pemikiran, (Jakarta: PT Raja Grafindo, 1993), 26 lihat juga Ensiklopedi Hukum Islam, (Jakarta: PT Ichtiar Baru Van Hoeve, 2003), Jilid 2, h. 365
} 
republik Arab Mesir. Beliau tumbuh di keluarga yang agamis dan berperadaban, dengan pertanian sebagai mata penghasilan. Orang tuanya meninggal dunia ketika beliau masih berumur dua tahun, oleh sebab itu beliau dipelihara oleh pamannya. Pamannya inilah yang mengantarkan Qardhawi kecil ke surau tempat mengaji. Di tempat tersebut Qardhawi terkenal sebagai seorang anak yang sangat cerdas.

Pendidikan menengah pertama (ibtidâiyah) diselesaikan di institusi al-Azhar yang berada di Provinsi Thanta, kemudian melanjutkan ke jenjang strata satu (licence) di Fakultas Ushuluddin Universitas Al-Azhar Kairo Tahun 1952. Karir akademiknya dilanjutkan ke almamater yang sama untuk menempuh program Pascasarjana. Kemudian tahun 1954 mendapat rekomendasi mengajar dari Fakultas Bahasa dan Sastra. Pada tahun 1958 ia mendapat gelar diploma dari Ma'had Dirâsat al-'Arabiyah dalam bidang bahasa dan sastra. Meraih gelar doktor pada tahun 1973 pada jurusan hadis dengan judul al-Zakât wa Atharuhâ fi hall al-Mashâkil al-ijtimâiyah. Disertasi Qardhawi tentang zakat banyak digunakan oleh dunia Islam sampai saat ini. ${ }^{17}$

Qardhawi telah mewariskan khazanah keintelektualan yang begitu banyak, namun sayangnya Qardhawi sampai saat ini belum membina muridmurid yang khusus guna menyebarkan buah pikiran dan pandangan-pandangannya. Karya-karya Qardhawi yang masyhur diantaranya, Al-Halâl wa alHarâm fì al-Islâm, Al-Fatâwâ baina al-Indhibât wa al-tasayub,Fiqh al-Zakat (2 juz), Min fiqh al-daulah $f$ al-Islâm, Fatâwa mu'ashirah (3 Juz), Taysir al-Fiqh: Fiqh al-Shiyâm.

\section{Pemimpin Menurut Pandangan Yusuf Qardhawi}

Salah satu kedudukan manusia di bumi adalah sebagai khalifah. Hal ini dapat dipahami dari klausa surah al-Fathir yang berbunyi, Huwa 'lladzîja'alakum khalâifa al-ardh, ${ }^{18}$ "dialah yang nenjadikan kamu sebagai khalifah (pemimpin) di bumi". ${ }^{19}$ Pemimpin mempunyai kedudukan yang tinggi. Penganugerahan yang diberikan oleh syara' kepadanya bersesuaian dengan keadaan dan kedudukan serta tanggungjawab mereka yang begitu besar. Kedudukan mereka sama seperti kedudukan imam. Syariat menjadikan mereka sebagai pengganti Rasulullah SAW untuk menjaga agama dan membangun dunia. Di antaranya dalil yang

\footnotetext{
17 Moh. Thoriquddin, Relasi Agama Dan Negara, (Malang: UIN-Malang Press, 2009), h. 18

18 QS: Al-Fathir, h. 39

19 Abdul Mun'im Salim, Fiqh Siyâsah Konsepsi Kekuasaan Politik Dalam AlQur'an, (Jakarta; PT Raja Grafindo Persada, 1994), h. 110
}

menunjukkan tingginya kedudukan pemimpin yang adil di sisi syariat adalah, pertama, menghubungkan ketataatan kepada Allah dan ketaatan kepada Rasulullah SAW bersama dengan pemerintah. Kedua, bahwa sesungguhnya Allah menjadikan pemimpin sebagai benteng kepada yang lemah daripada yang kuat dan kepada mereka yang dizalimi. Sekiranya tidak ada pengawasan dari Allah yang diwakilkan kepada pemimpin niscaya tidak berlaku adanya keamanan dan hilanglah hak asasi manusia. ${ }^{20}$

Qardhawi menjelaskan bahwa seorang pemimpin dalam Islam merupakan wakil dari umat, atau lebih tepatnya adalah sebagai pegawai umat. Sebagai pengganti dari Rasulullah SAW dalam menegakkan agama dan mengatur dunia dengan agama. Diantara hak-hak yang mendasar, perwakilan tersebut dapat dicabut jika memang dikehendaki, terutama jika orang yang menjadi wakil mengabaikan berbagai kewajiban-kewajiban yang harus dilakukan. ${ }^{21}$ Pemimpin adalah orang yang mengatur segala urusan rakyat dan negara dibantu dengan para wakil dan para kabinetnya. Kabinet tersebut dipilih langsung oleh rakyat atau dipilih oleh pemimpin itu sendiri. Kemudian mendistribusikannya ke beberapa daerah untuk menjadi pemimpin di daerah tersebut. ${ }^{22}$

Qardhawi menyatakan bahwa ketaatan seorang rakyat kepada pemimpin adalah sebuah keharusan. Namun ia merinci lebih jauh mengenai konsep kewajiban seorang rakyat untuk taat kepada pemimpin dengan disertai beberapa syarat. Pertama, pendapat imam atau wakilnya yang tidak dilandasi nash yang multi tafsir dan yang berkaitan dengan berbagai kemaslahatan yang tidak terbatas, boleh dilaksanakan selagi tidak berbenturan dengan kaidah syar'iyah. Kedua, pendapat tersebut dapat berubah menurut perubahan kondisi, hukum adat dan tradisi. ${ }^{23}$

\section{Kedudukan dan Ruang Lingkup Aplikasi Ijtihad Ulil Amri}

Penting melihat kedudukan pemerintah di dalam pembahsan fiqh Siyâsah. Kedudukan tersebut akan mengantarkan kita untuk memahami seberapa kuat sebenarnya aturan-aturan yang dibuat oleh pemerintah.

\footnotetext{
20 Khalid Bin Ali Bin Muhammad Al-'Anbary, Sistem Politik Islam, Menurut al-Qur'an, Sunnah \& pendapat Ulama Salaf, (Kuala Lumpur, Telaga Biru, 2008), h. 122-123

21 Yusuf Qhardhawi, "Min al-Fiqh al-Daulah fi al-Islam", diterjemahkan oleh Khatur Suhardi, Fiqh Daulah Dalam Perspektif al-Qur'an dan Al-sunnah, (Cet. I, Pustaka al-Kausar, 1997). h. 190

22 Yusuf Qardhawi, "Al-Siyâsat Al-Syar'iyah, diterjemahkan oleh Khatur Suhardi, "Pedoman Bernegara Dalam Perspektif Islam, (Cet: 1, Jakarta: Pustaka Kaustar: 1999), h. 50

23 Qardhawi, al-Siyâsat, h. 49
} 
Pada dasarnya, peraturan-peraturan pemerintah yang dibuat dan diberlakukan dalam perkara-perkara yang tidak ada nash-nya haruslah mengandung dan berkaitan dengan masalih al- mursalah. Maka sebelum pemimpin membuat sebuah keputusan, terlebih dahulu permasalahan tersebut dimusyawarahkan kepada ahli di bidangnya, ${ }^{24}$ sebagaimana firman Allah SWT yang berbunyi:

\section{Maka disebabkan rahmat dari Allah-lah kamu} Berlaku lemah lembut terhadap mereka. Sekiranya kamu bersikap keras lagi berhati kasar, tentulah mereka menjauhkan diri dari sekelilingmu. karena itu ma'afkanlah mereka, mohonkanlah ampun bagi mereka, dan bermusyawaratlah dengan mereka dalam urusan itu. kemudian apabila kamu telah membulatkan tekad, Maka bertawakkallah kepada Allah. Sesungguhnya Allah menyukai orang-orang yang bertawakkal kepada-Nya ${ }^{25}$

Ayat di atas menerangkan bahwa musyawarah adalah sesuatu yang diperintahkah dalam al-Qur'an, maka lafadz perintah pada dasarnya adalah menunjukkan sebuah kewajiban. Jika seorang rasul diperintahkan untuk bermusyawarah, maka sudah pasti sebagai umat nabi Muhammad SAW juga diperintahkan. Imam Syafi'I dalam kitab al-Umm mengatakan "sesungguhnya Nabi tidak butuh bermusyawarah tetapi beliau berkeinginan agar hal tersebut diikuti oleh hakim dan para pemimpin setelahnya". ${ }^{26}$

Ulîl amri boleh untuk berpendapat, namun menurut Qardhawi pendapat seorang ulîl amri dapat diaplikasikan dalam pada tiga ruang lingkup sebagaimana di bawah ini: ${ }^{27}$ (1) Hal-hal Yang Tidak Ditetapkan Nash. Ruang lingkup pertama adalah masalah-masalah yang tidak mempunyai nash. Artinya, masalah-masalah yang tidak ada dalil syariatnya dalam al-Qur'an maupun al-Sunnah, atau yang sudah diatur tetapi tidak secara khusus. Sebagaimana yang diriwayatkan oleh Abu Darda' dari Nabi, beliau bersabda:

"Apa yang dihalalkan Allah di dalam kitabNya, maka ia halal, dan apa yang diharamkan Allah, maka ia haram, dan apa yang didiamkan adalah dimaafkan"

Qardhawi menyimpulkan, bahwa apa yang dimaksud sesuatu yang tidak ada ketetapan nash-nya, bisa jadi sesuatu tersebut tidak ada dalilnya, atau ada

\footnotetext{
24 Qardhawi, al-Siyâsat, h. 69

25 Al-Imran (3): 159

26 Imam Syafi' I, Al-umm, diterjemahkan oleh Abu Abdullah Muhammad Idris, Ringkasan Kitab al-Umm, (Jakarta: Pustaka Azam, 2006), h. 117

27 Qardhawi, Al-siyasat.
}

dalilnya yang bersifat global seperti nash tentang bermusyawarah yang disebutkan dalam firman Allah, "Dan bermusyawarahlah dengan mereka dalam urusan itu"28 begitu pula firman-Nya "sedang uruusan mereka (diputuskan) dengan musyawarah antara mereka" ${ }^{29}$

Dari ketentuan ayat di atas, masih bersifat universal dan belum menyentuh aspek-aspek partikular dalam hal teknisnya, misalnya mengenai siapakah yang harus bermusyawarah, kemudian bagaimana cara pengangkatannya, apa saja yang boleh dimusyawarahkan, bagaimana jika saling terjadi perbedaan. Hal-hal tersebut belum disebutkan dengan jelas, maka aplikasi dari ayat tersebut diserahkan sepenuhnya kepada mujtahid, dan merupakan rahmat dari Allah SWT. Dalam kasus seperti inilah, pemerintah memiliki sebuah kewenangan untuk melakukan ijtihad, yaitu dalam hal-hal yang belum diatur secara tegas oleh syariat. (2) Masalah-masalah Yang Memiliki Beberapa Alternatif. Lingkup kedua yang memberikan tempat bagi pendapat pemimpin untuk diaplikasikan ialah masalah yang mengandung beberapa alternatif. Jika masalah ini terjadi, maka ada tiga pilihan diantaranya: Pertama, Diserahkan Kepada Pilihan Pemimpin. Syariat menyerahkan pilihan kepada pemimpin dalam menghadapi dua urusan atau lebih, sehingga dia bisa memilih salah satu diantaranya. Pada dasarnya pemerintah mempunyai pandangan-pandangan yang berbeda dengan rakyatnya mengenai sebuah persoalan. Hakikatnya pemerintah mempunyai pandangan luas dalam menghadapi persoalan dan harus bersikap mengedepankan kemaslahatan dalam mengambil setiap keputusan. Namun yang harus menjadi catatan, bahwa seorang pemerintah tidak boleh menjatuhkan keputusannya yang mengikuti hawa nafsunya dan keinginan hatinya atau menjatuhkan pilihan semaunya sendiri tanpa dilandasi alasan. ${ }^{30}$

Kedua, Terdapat Beberapa Macam Pendapat dan Ijtihad. Pemerintah mempunyai kewenangan untuk berijtihad salah satunya dalam persoalan yang memiliki beberapa alternatif. Diantaranya ada mempunyai beberapa ijtihad atau pendapat, yang mana pendapat tersebut berbeda satu dengan yang lain, sementara tidak ada nash kongkrit yang bisa menuntaskan perbedaan dan menyelesaikan perselisihan.

Jika dilihat, hukum-hukum fiqh Islam termasuk dalam kategori di atas, karena banyak sekali terjadi

\footnotetext{
28 QS: Al-Imran (3): 159

29 QS: Al-Syura (26): 38

30 Yusuf Qardhawi, “Al-Siyasat, h. 71
} 
perbedaan-perbedaan di kalangan fuqaha, dan sangat sedikit nash qath' $i$ yang membahas suatu hukum. Maka kewajiban seorang ulîl amri adalah melakukan ijitihad untuk memilih alternatif atau men-tarjih dari beberapa pendapat yang sudah ada. Yang dianggap mempunyai dalil yang kuat dan diyakini sebagai alternatif pemecahan yang paling dekat dengan pengejawantahan tujuan-tujuan syariat dan kemaslahatan.

Ketiga, Kemaslahatan Terikat (Maslahat alMursalah). Salah satu lingkup dari ijitihad ulîl amri dalam politik syar'iyah adalah maslahah almursalah. Maslahah al-Mursalah adalah termasuk dalam kategori masalah-masalah yang belum ada dalil nash-nya. Namun maslahah al-mursalah mempunyai batasan tersendiri, makna kemaslahatan adalah segala sesuatu yang di dalamnya terkandung kebaikan dan manfaat bagi manusia dalam urusan dunia maupun akhiratnya. ${ }^{31}$

Penggunaan maslahat ini didasarkan pada banyaknya dilil-dalil umum yang menjelaskan bahwa syariat sangat mempehatikan terhadap kemaslahatan manusia, dan memang yang menjadi tujuan syariat. Imam yang paling banyak menggunakan "maslahah al-mursalah" adalah imam Malik dan para pengikutnya. Imam yang paling jarang menggunakan maslahah al-mursalah adalah imam Syafi'i.

\section{Konsep Musyawarah Qardhawi}

Di antara nilai-nilai kemanusiaan dan sosial yang di bawa Islam adalah musyawarah (syura). Pengertiannya adalah bahwa hendaknya seseorang tidak menyendiri dalam persoalan-persoalan yang memerlukan kebersamaan pikiran dengan orang lain. Musyawarah dalam suatu urusan dapat membuka pintu kesulitan dan memberi kesempatan untuk melihat urusan itu dari berbagai sudut, sesuai dengan perbedaan pandangan setiap individu, perbedaan tingkat pemikiran, dan tingkat pengetahuan mereka. Keputusan yang diperoleh pun berdasarkan persepsi dan studi yang komprehensif. Diantara prisnsipprinsip musyawarah untuk menyelasaikan persoalanpersoalan sebagaimana yang dikatakan oleh Qardhawi adalah sebagai berikut: (1) Pendapat Mayoritas Harus Diikuti. Musyawarah dalam kehidupan bermasyarakat dan bernegara di dalam al-Qur'an menempati unsur yang terpenting dalam berjamaah (organisasi). Hal tersebut banyak disebutkan dalam al-Qur'an sebagai acuan dalam membentuk dasar-dasar ke-

31 Yusuf Qardhawi, “Al-siyâsat, h. 80 hidupan Islam. ${ }^{32}$ Hal ini sebagaimana dicontohkan oleh Rasulullah SAW, bahwa Rasul sendiri sering bermusyawarah dengan para sahabat-sahabatnya. Seperti dalam peristiwa perang Uhud, ketika waktu itu umat muslim mengalami kekalahan sehingga mengakibatkan tujuh puluh syuhada dari para sahabat wafat. Meskipun Rasulullah SAW sebagai pemimpin umat Islam, beliau tidak langsung memutuskan perkara dengan sendirinya, melainkan mengajak para sahabat lain untuk bermusyawarah. Tak jarang Rasulullah mendapati para sahabat yang berbeda pendapat dengan beliau, maka beliau mengambil pendapat yang ditawarkan tersebut dan meninggalkan pendapatnya sendiri. ${ }^{33}$ (2) Kebijakan Imam Harus Mengikuti Prinsip Kemaslahatan. Ijtihad pemerintah (ulîl amri) pada dasarnya harus berdasarkan atas kaidah mencari dan memelihara kemaslahatan serta mencegah dan menghilangkan kemadharatan, perpecahan diantara umat (masyarakat). Al-Qarafi menyatakan bahwa mashâlih mursalah sebagai dasar dari dasar-dasar ilmu fikih. ${ }^{34}$ Hal ini mengambarkan bahwa kemaslahatan adalah sebagai bagian penting dalam sebuah hukum. Di antara kaidah syar'iyah yang amat penting dalam bab ini dan menjadi batasan aplikasi pendapat imam ialah kaidah yang berbunyi:

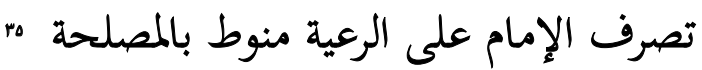

"Kebijakan imam (pemimpin) terhadap rakyatnya itu harus dihubungkan dengan kemaslahatan"

Qaidah fiqhiyyah di atas memberikan penjelasan bahwa setiap tindakan atau kebijakan para pemimpin yang menyangkut dan mengenai hak-hak rakyat dikaitkan dengan kemaslahatan rakyat banyak yang ditujukan untuk mendatangkan kebaikan. ${ }^{36}$ (3) Hasil Musyawarah adalah Keputusan Yang mengikat. Setelah melakukan musyawarah, kemudian terjadi sebuah kesepakatan. Maka pada dasarnya kesepakatan tersebut adalah pedoman bagi setiap peserta musyawarah. Artinya kesepakatan hasil musyawarah tidaklah sekedar dianggap sebagai masukan atau sebuah rekomendasi belaka dan tidak mengikat. Kalau

32 Yusuf Qardhawi, Malâmih al-Mujtma' Al-Muslim Aladzi Nunsyiduhu, diterjemahkan oleh Abdus Salam Masykur, "Mayarakat Berbasis Syariat Islam Akidah, Ibadah, akhlak, (Solo: Era Intermedia, 2003), h. 200

33 Qhardhawi, Malâmih,

34 Farid Abdul Khaliq, Fî Al-Fiqh Al-Siyâsy Al-Isâmy Mabâdi' Dusturiyyah Asy-Syûra Al-'adl Al-Musâwâh, diterjemahkan oleh Fathurrahman A. Hamid, Fikih Politik Islam, (Jakarta: Amzah, 2005), h. 94-95

35 Abdul al-Rahman bin Abî Bakr al-Suyuthi, al-Asbah wa al-Nadhair,Juz I cet. pertama (Dar Kutub al-Alamiah, 1983), h. 233

36 Musbikin, Qawa'id Al-Fiqhiyyah, (Jakarta: PT Raja Grafindo Persada, 2001), h. 124 
dikatakan demikian, maka musyawarah yang sudah dilaksanakan oleh pemerintah tidak ada gunanya. ${ }^{37}$

Ibnu Katsir menyebutkan di dalam tafsirnya, yang diriwayatkan oleh Ibnu Marduwiah dari Abu Thalib RA, bahwa dalam setiap urusan mereka bermusyawarah, kemudian meminta pertimbangan Ahli Syura lalu mengikutinya, berikut bunyi haditsnya:

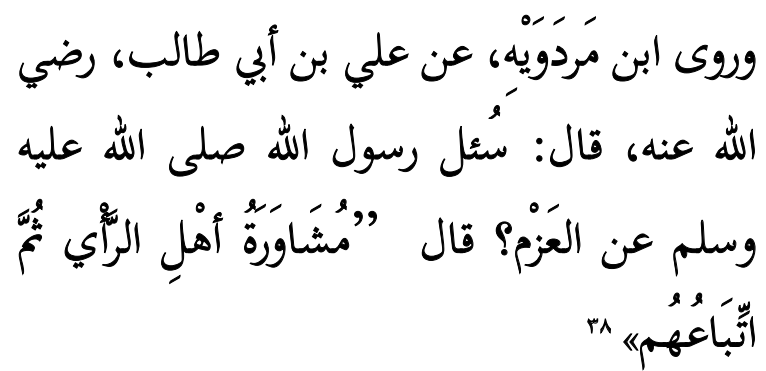

Sekalipun ada perbedaan pendapat, jika umat atau segolongan umat mengambil keputusan untuk kembali kepada musyawarah, tentu perbedaan pendapat dapat diminimalis. Kemudian mengambil hasil musyawarah tersebut sebagai pijakan dan diikuti bersama.

\section{Otoritas Pemerintah dalam Penetapan Awal Bulan Qamariyah Perspektif Fiqh Siyâsah Yusuf Qardhawi}

Kementerian Agama merupakan representasi dari pemerintah yang pada hakikatnya menjembatani perbedaan yang terjadi dalam penetapan awal bulan. Sesungguhnya kehadiran pemerintah dalam masalah tersebut membawa manfaat bagi masyarakat awam, dengan andilnya pemerintah dalam penetapan awal bulan memberikan kejelasan tentang awal bulan Qamariyah.

Namun, persoalannya apakah keikutsertaan pemerintah dalam hal penetapan awal bulan merupakan sebuah keharusan dengan alasan untuk mengatur ketertiban dalam masyarakat. Maka dalam bab ini akan diuraikan tentang otoritas pemerintah dalam menetapkan awal bulan. Penting untuk melihat aspek otoritas pemerintah, karena dengan melihat aspek ini kita akan menjadi lebih tahu apakah sebenarnya pemerintah mempunyai kewenangan atau tidak dalam hal penetapan awal bulan.

Untuk menuju kepada pembahasan otoritas pemerintah, maka terlebih dahulu penulis akan melakukan analisis dari beberapa aspek. Diantaranya mengenai beberapa aspek-aspek berikut. Pertama, melihat kembali apakah Kementerian Agama benar-

37 Qardhawi, As-siayasat,

38 Maktabah Syamilah, Ibnu Katsir, juz 2, h. 150 benar merupakan representasi dari pemerintah ketika dilihat dari fiqh Siyâsah. Kedua, melakukan analisis tentang ruang lingkup ijtihad pemerintah itu sendiri. Apakah penetapan awal bulan Qamariyah termasuk dalam ruang lingkup ijtihad kewenangan pemerintah atau bukan.Ketiga, mekanisme musyawarah dalam penetapan awal bulan yang dijalankan oleh pemerintah, dan keempat, setelah diputuskan penetapan awal bulan tersebut, apakah putusan tersebut membawa maslahat kepada masyarakat atau sebaliknya. Untuk lebih jelasnya akan diuraikan sebagaimana berikut:

\section{Aspek kepemerintahan}

Pemerintahan Indonesia sebagaimana tertuang dalam Undang-Undang Dasar adalah negera Republik Indonesia ialah negara kesatuan yang berbentuk republik. Sedangkan dalam pemilihan kepala pemerintahan (Presiden) dan wakil presiden dilakukan secara langsung oleh rakyat melalui pemilihan umum (Pemilu) ${ }^{39}$ Mereka yang terpilih dianggap sebagai seseorang atau kelompok yang mempunyai kewajiban untuk bicara, bertindak atas nama suatu kelompok yang lebih besar (masyarakat) melalui partai politik..$^{40} \mathrm{Di}$ Indonesia sendiri menganut sistem multi-partai dalam pelaksanaan pemilu. Partai politik merupakan sebuah ciri khas dari negara yang menganut sistem demokrasi.

Qardhawi berpendapat bahwa sistem pemilihan umum sama halnya dengan pemberian kesaksian. Pemilih memberikan kesaksian kelayakan kepada kandidat calon. Dengan memilih, berarti yang bersangkutan telah memberikan kesaksian kepada calon tersebut bahwa calon tersebut layak untuk menjadi pemimpin. Adapun dengan pemberlakuan sistem partai, ia beranggapan tidak ada larangan untuk memberlakukan sistem multi-partai dalam sebuah negara Islam. ${ }^{41}$ Selanjutnya dia menambahkan bahwa kebutuhan untuk mendirikan sebuah partai merupakan hal yang dharuri (mendesak). Sebab, sistem tersebut menjamin keselamatan rakyat dari pemerintahan diktator individu atau diktator golongan tertentu yang sering berlaku semena-mena. ${ }^{42}$

Dari sini bisa disimpulkan bahwa, pemerintahan yang dipilih melalui pemilihan umum dengan

39 Titik Triwulan Tutik, Konstruksi Hukum Tata Negara Indonesia Pasca Amandemen UUD 1945, (Jakarta: Kencana, 2010), h. 375

40 Mahfud M.D, Politik Hukum Indonesia, Edisi Revisi, (Jakarta: PT Raja Grafindo, 2010), h. 61

41 Karakteristik Negara Islam menurut pandangan Yusuf Qardhawi bukanlah negara "agama", akan tetapi sebuah negara madani berefensi Islam, negara shariah dustûriyah, negara dengan mengedepankan sistem permusyawaratan, melindungi yang lemah, menjaga kebebasan, penuh dengan dasar akhlak, karena semuanya sesuai dengan tujuan serta inti ajaran Islam. baca buku Qardhawi, Min al-fiqh fi al-Daulah al-Islam.

42 Qardhawi, Min al-Fiqh, h. 208 
mekanisme partai politik, menurut Qardhawi sudah dianggap sah dalam artian diakui oleh syara'. Oleh karena itu, ketika sudah sah dan diakui syara' maka perintahnya adalah menjadi sebuah kewajiban. Selanjutnya, apabila pemilihan kepala pemerintahan (presiden) dianggap sah maka pemerintahan yang dibentuknya pun sudah dianggap sah pula.

\section{Ruang lingkup kewenangan aplikasi pendapat pemerintah}

Setelah melihat analisis dari aspek kepemerintahan, langkah selanjutnya adalah melakukan analisis ruang lingkup pendapat (ijitihad) pemerintah. Dalam kajian teori pada bab sebelumnya sudah dijelaskan pokok-pokok pemikiran Qardhawi tentang batas aplikasi pendapat pemerintah. Diantaranya ada tiga hal, pertama, dalam hal-hal yang tidak ditetapkan oleh nash al-Qur'an, kedua, masalah-masalah yang memiliki beberapa alternatif. Dan yang ketiga, dalam kategori maslahah al-mursalah. ${ }^{43}$

Dalam penetapan awal bulan Qamariyah, jika merujuk kepada tiga kategori di atas, nampaknya persoalan penetapan awal bulan tersebut lebih mendekati kepada masalah-masalah yang mempunyai beberapa alternatif. Maksud dari beberapa alternatif di sini adalah mempunyai lebih dari satu pilihan hukum (pendapat). Seperti boleh membebaskan, menerima tebusan, menjadikan tawanan atau budak dan dihukum mati, bagi tawanan perang. Maka pemerintah mempunyai kewenangan untuk memilih satu dari beberapa alternatif hukum. Masalah penetapan awal bulan Qamariyah di Indonesia, mempunyai lebih dari satu metode penetapan awal bulan Qamariyah. Metode tersebut adalah metode hisab dan rukyah. Maka dari analisis ini, dapat disimpulkan bahwa keikutsertaan pemerintah dalam hal menetapkan awal bulan Qamariyah, penulis berpendapat sudah termasuk dalam ruang lingkup ijtihad pemerintah. Dan tidak dianggap keliru jika pemerintah menetapkan awal bulan karena termasuk dalam ruang lingkup ijtihad pendapatnya.

\section{Mekanisme penetapan awal bulan qamariyah}

Setelah melakukan analisis tentang ruang lingkup pendapat pemerintah, selanjutnya hal yang paling penting adalah melihat proses penetapan atau mekanisme penetapan awal bulan Qamariyah yang telah dilakukan oleh kementerian agama RI. Melihat proses mekanisme ini merupakan hal yang sangat urgen dalam masalah penetapan awal bulan, karena berawal dari proses tersebut hasil putusan

43 Qarlawi, Al-Siyasat, h. 71-80 ketetapan awal bulan dikeluarkan dan sepakati. Analisis ini akan mengarah kepada mekanisme yang digunakan oleh Kementerian agama, apakah sudah benar-benar disepakati oleh semua kelompok, dan dalam pelaksanaannya apakah benar-benar dilakukan dengan adil dan tidak ada pihak yang merasa terdiskriminasikan.

Setelah mengamati pemerintah dalam hal mekanisme penetapan awal bulan, sebagaimana yang sudah diuraikan dalam bab sebelumnya. Bahwa metode pengambilan keputusan yang dipergunakan oleh pemerintah dengan cara bermusyawarah dengan semua pihak yang mempunyai kapasitas dan kapabilitas terhadap masalah penetapan awal bulan adalah merupakan cara yang sangat demokratis.

Islam mengajarkan seorang muslim untuk selalu menyelesaikan sebuah persoalan dengan jalan bermusyawarah, sebagaimana di uraikan dalam al-Qur'an dan al-sunnah begitu juga yang dipraktekkan oleh Rasulullah SAW. Maka dari itu, pilihan Kementerian Agama untuk menyelesaikan persoalan penetapan awal bulan Qamariyah dengan musyawarah sejatinya merupakan kebijakan yang shahih.

Tidak sampai di sini, pemerintah juga sudah melibatkan tim ahli di dalam menentukan awal bulan Qamariyah, seperti Badan Meteorologi dan Geofisikia (BMKG), Lembaga Antariksa, Penerbangan Internasional dan Observatorium Bosscha. Senada dengan hal tersebut, Qardhawi menjelaskan bahwa dalam menetapkan sebuah permasalahan haruslah ditempuh dengan jalan bermusyawarah, dan apabila diperlukan boleh mendatangkan tim ahli. ${ }^{44}$ Pendapat ini diperkuat oleh At-Tabhari dalam al-Awsaht dan Abû Said dalam al-Qadhâ sebagaimana yang dikemukakan di dalam al-Manâr:

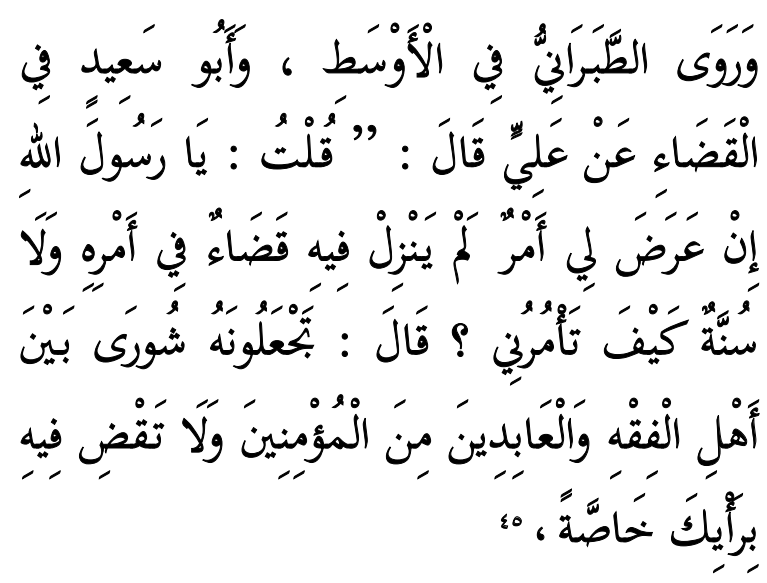

44 Qardhawi, Al-Siyâsah,

45 Al-Manâr, Juz 5, Hal, 160, Diambil dari Maktabah Syamila II. 
Bahwa dalam hadits tersebut dijelaskan bahwa Rasulullah SAW memerintahkan untuk membahas perkara yang tidak ada ketetapan hukum dalam alQur'an maupun al-Sunnah dengan para ahli fikih dan ahli agama dari kaum mukminin. Artinya dalam setiap masalah harus di selesaikan dengan pertimbangan ahli hukum. Hal ini dimaksudkan agar, keputusan hukum yang dikeluarkan tidak melenceng atau salah. Tindakan Kementerian Agama untuk menggandeng tim ahli dalam masalah antariksa, perbintangan dan cuaca dalam menetapkan awal bulan Qamariyah guna meminta pertimbangan adalah suatu tindakan yang tepat guna menghindari keputusan yang salah.

Sedangkan dalam metode pengambilan keputusan, Menteri Agama tidak serta merta menetapkan sesuai dengan kehendaknya. Akan tetapi melalui musyawarah dengan peserta rapat dengan mempertimbangkan saran atau masukan dari peserta sebelumnya. Kemudian pemerintah menyimpulkan dari hasil musyawarah dan menawarkan kembali kepada peserta sidang, jika semua peserta satu pendapat (tidak ada perbedaan) maka pemerintah menetapkan sebagaimana hasil musyawarah tersebut. Namun jika terjadi perbedaan pendapat maka suara mayoritas adalah suara yang dipertimbangkan untuk diambil pendapatnya guna dijadikan sebuah ketetapan.

Qardhawi menjelaskan dalam sebuah perselisihan pendapat yang paling diunggulkan (diprioritaskan) adalah jumlah yang terbanyak (mayoritas). Ia beranggapan bahwa pendapat dua orang atau lebih dekat kepada kebenaran daripada pendapat satu orang. Dalam sebuah hadits dijelaskan bahwa syaithan menyertai satu orang dan lebih jauh dari dua orang.

$$
\begin{aligned}
& \text { حدثنا أحمد بن منيع حدثنا النضر بن إسما عيل أبو } \\
& \text { المغيرة عن محمد بن سوقة عن عبد الله بن دينار عن } \\
& \text { ابن عمر قال: ... عليكم بالجماعة وإياكم والفرقة فإن } \\
& \text { الشيطان مع الواحد وهو من الاثنين أبعد"؟ }
\end{aligned}
$$

Dengan kata lain, pendapat dua orang bisa mengungguli satu pendapat selagi dalam masalahmasalah diluar syariat dan apa yang disampaikan dari Allah SWT. ${ }^{47}$ Dapat disimpulkan bahwa Kementerian Agama dalam menetapkan masalah awal bulan juga

\footnotetext{
46 Muhammad bin 'Isa Abû 'Isa al-Thirmidzi, Al-Jâmi' Al-Shohih Sunan alThirmidzi, Juz 4 (Beirut: Dâr Ihya al-Turats al-'Arabi), 465. Menurut AlThirmidzi, hadits ini hasan shahih gharib yang diriwayatkan dari Umar.

47 Qardhawi, Min al-Fiqh, h. 200
}

menerapkan sistem musyawarah dan mendatangkan tim ahli. Selanjutnya dalam menetapkan keputusan, pemerintah memberikan kesempatan setiap kelompok untuk menyampaikan aspirasinya. Dan sudah mengikut sertakan ormas-ormas Islam. Oleh karena itu, mekanisme sidang tersebut sudah menunjukkan arah demokratis dan tidak otoritatif.

\section{Keputusan pemerintah}

Qardhawi menjelaskan bahwa keputusan pemerintah harus mencerminkan kemaslahatan. Mayoritas ulama menyatakan bahwa muara dari pada hukum haruslah mengandung kemaslahatan. Begitu pula keputusan pemerintah dalam penetapan awal bulan harus mengandung maslahat. ${ }^{48}$ Ketika diamati, bahwa masyarakat merasa kebingungan, merasa tidak ada kepastian kapan mereka harus mengawali dan mengakhiri bulan Ramadhan misalnya. Meskipun ada beberapa ormas Islam yang mengumumkan kepada anggotanya terkait awal bulan Qamariyah, misalnya satu Syawal. Namun, tidak semua masyarakat mengikuti ormas-ormas tertentu, apalagi bagi mereka yang masih awam dengan masalah agama. Maka sungguh tidak ada kepastian dalam hal awal bulan bagi mereka masyarakat awam. Oleh karena itu, keputusan pemerintah dalam penetapan awal bulan Qamariyah memberikan manfaat berupa kejelasan terhadap permasalahan penetapan awal bulan Qamariyah.

Selanjutnya dalam keputusan pemerintah tersebut juga membawa kemaslahatan berupa persatuan dan kesatuan umat. Karena dengan mengikuti ketetapan pemerintah maka tidak akan ada lagi perbedaan penetapan awal bulan. Karena mengacu kepada qaidah fiqh yang berbunyi:

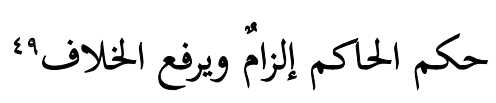

Setelah mengamati dan menganalisis berbagai aspek diatas, Kesimpulannya, pemerintah dalam hal ini Kementerian Agama Republik Indonesia mempunyai otoritas dalam hal penetapan awal bulan Qamariyah. Artinya pemerintah berwenang menetapkan (itsbat) awal bulan Qamariyah. Sedangkan orang, instansi atau ormas Islam diluar pemerintah pada hakikatnya tidak ada kata itsbât bagi awal bulan ramadhan. ${ }^{50}$ Namun hanya sebatas ikhbâr (mengumumkan) kepada anggota-anggotanya masing-masing. Karena

\footnotetext{
48 Qardhawi, al-Siyasat, h. 107

49 Lihat catatan kaki nomor 10

50 Baca, Ahmad Izzudin, Fiqh Hisab Rukyah Menyatukan NU dan Muhammadiyah dalam Menetukan Awal Ramadhan, Idul Fitri, dan Idul Adha, (Jakarta: Erlangga, 2007), h. 150-151
} 
kewenangan sepenuhnya dalam penetapan awal bulan hanya pada pemerintah.

\section{Status Hukum Menaati Pemerintah Dalam Penetapan Awal Bulan Qamariyah}

Dalam pelaksanaannya, ketetapan pemerintah tentang awal bulan Qamariyah Kementerian Agama direspon baik oleh masyarakat luas. Pemerintah sebagaimana pembahasan di atas mempunyai otoritas dalam menentukan (itsbat) awal bulan Qamariyah. Dalam pembahasan ini akan dilakukan kajian mengenai status hukum menaati pemerintah dalam penetapan awal bulan Qamariyah perspektif fiqh Siyâsah Yusuf Qardhawi.

Sebelum memulai untuk analisis, perlu diketahui bahwa permasalahan penetapan awal bulan adalah permasalah furu' bukan permasalahan ushîl. Oleh karena itu ia termasuk kedalam ketegori fiqh atau ijtihâdi, sehingga banyak terjadi perbedaan. Maka sesungguhnya permasalahan tersebut menerima ijtihad baru ataupun tajdîd dan setiap orang mempunyai kebebasan untuk berijtihad sesuai dengan kemampuannya masing-masing. Namun ketika permasalahan tersebut sudah diadopsi atau ditetapkan oleh pemerintah, maka menurut Qardhawi rakyat tersebut harus mengikuti pendapat yang sudah ditetapkan oleh ulîl amri tersebut. Karena wajib hukumnya untuk mengikut kepada ulîl amri. ${ }^{5 l}$ Karena menurut Qardhawi, selama kebijakan atau perintah dari pemerintah masih sejalan dengan ruh-ruh Syariat dan tidak menyuruh kepada kemaksiatan, maka tidak ada alasan bagi rakyat untuk tidak mematuhi perintah tersebut.

Upaya pemerintah yang berpijak pada upaya tercapainya keseragamaan, kemaslahatan, dan persatuan ummat Islam Indonesia tidak sepenuhnya diterima oleh masyarakat luas. Ormas-ormas Islam justru membuat keputusan sendiri-sendiri sesuai dengan metode yang diyakininya. ${ }^{52}$ Meskipun pada hakikatnya hanya sekedar mengumumkan, seolaholah pengumuman tersebut wajib dipengangi oleh setiap anggota/pengikut ormas-ormas tersebut. ${ }^{53}$

Padahal secara hakikatnya, yang mempunyai otoritas untuk menetapkan masalah awal bulan Qamariyah adalah pemerintah dengan kekuasaan itsbât-nya, sedangkan kalaupun ada organisasi atau ormas diluar pemerintah yang menetapkan, sifat ketetapan tersebut hanya sebatas ikhbâr (mengumumkan) bukan

\footnotetext{
51 Qardhawi, al-Siyâsat, h. 50

52 Ahmad Izzudin, Figh Hisab, h. 150

53 Ahmad Izzudin, Figh Hisab
}

itsbât (menetapkan). Hal ini menurut analisis penulis, terjadinya perbedaan penetapan awal bulan Qamariyah di Indonesia dikarenakan masyarakat ataupun ormas-ormas Islam tidak sepenuhnya menyerahkan permasalah tersebut kepada pemerintah. Tidak seperti persoalan perkawinan, zakat, wakaf dan haji yang masyarakat percaya untuk menyerahkan persoalan tersebut kepada pemerintah, namun tidak untuk persoalan penetapan awal bulan ini. Hal ini menunjukkan bahwa masyarakat tidak totalitas menyerahkan permasalahan tersebut kepada pemerintah dalam hal ini Kementerian Agama. Padahal, masyarakat dan ulama sudah sepakat untuk menyerahkan persoalan keagaman kepada pemerintah, kemudian pemerintah menunjuk Kementerian Agama untuk mengemban amanah tersebut. Kementerian Agama pun di dalamnya terdiri dari para ulama, cendekiawan, dan para ahli dibidangnya.

Dalam hal berselisih penetapan dengan pemerintah, ketika seseorang sudah meyakini kebenaran awal bulan tersebut, ulama pada zaman dahulu berselisih pendapat. Diantaranya: Pertama, Seseorang tersebut boleh berpuasa bila melihat Ramadhan dan berbuka apabila melihat hilâl Syawal secara sembunyi-sembunyi agar tidak kelihatan menyelisihi kaum muslimin yang lain. Maksud dari perintah untuk berbuka secara sembunyi-sembunyi agar tidak menimbulkan perpecahan diantara umat Islam. Pendapat ini dipegang oleh mazhab Imam Syafi'I, mereka berdasarkan pada hadits yang secara mutlak memerintahkan untuk berpuasa dan berbuka dengan melihat hilâl (sûmû li al-rukyâtihi wa al-afthirû li alrukyâtihi). Hal ini sebagaimana dijelaskan oleh Imam Nawawi dalam kitab Majmu' Syarah Muhazzab. ${ }^{54}$

Kedua, Seseorang tersebut berpuasa jika melihat hilâl Ramadhan, namun untuk berbuka dan berhari raya maka dia mengikuti bersama umat Islam lainnya. ${ }^{55}$ Ini menurut mazhab Imam Abu Hanifah, Malik dan yang Mashur dari mazhab Imam Ahmad.

Ketiga, Seseorang tersebut tidak boleh mengikuti rukyahnya, yang wajib baginya untuk berpuasa dan berbuka mengikuti kaum muslimin lainnya. Ini merupakan pendapat Imam Ahmad dan dikuatkan oleh Ibnu Taimiyah. ${ }^{56}$

\footnotetext{
54 Âbu Zakaria Muhyiddin Yahya bin Syaraf al-Nawawi, Majmu' Syarah Muhazzab, juz II, tt.th. h. 280

55 Mâlik bin Anas bin Mâlik bin Âmir, Al-Mudawanah, juz 1, (Beirut: Dâr al-Kutub al-'Alamiah), h. 226-227

56 Ahmad Sabiq bin Abdul Lathif Abu Yusuf, Bid'ahkah Ilmu Hisab?! Kajian tentang Ilmiah Tentang polemik Hisab Rukyah Untuk Menetapkan Puasa Ramadhan dan Hari Raya, (Gresik: Pustaka Fuqon, 2011), h. 162
} 
Berpijak dari ketiga pendapat diatas, penulis berkesimpulan bahwa tujuan dari ketiga pendapat tersebut salah satunya adalah untuk menjaga kemaslahatan yakni terciptanya persatuan dan kesatuan internal umat Islam. Dapat dilihat dari pendapat Imam Syafi'i yang memperbolehkan untuk berpuasa dan berbuka menyelisihi khalayak ramai atau masyarakat. Akan tetapi harus secara sembunyi-sembunyi agar tidak terlihat menyelisihi umat Islam yang lain. Abu Hanifah dan Imam Malik, memperbolehkan untuk berpuasa terlebih dahulu, akan tetapi ketika berbuka atau lebaran ia harus mengikuti umat Islam lainnya. Begitu juga Ibnu Taimiyah yang mewajibkan untuk mengikuti umat muslim lainnya dan tidak memperbolehkan untuk berbuka ataupun berpuasa sendirian. Ini tidak lain hanya untuk menjaga kebersamaan, kesatuan dan persatuan umat Islam. Sehingga hemat penulis tujuan dari ketiga qaul tersebut adalah untuk menciptakan persatuan dan kesatuan umat, dan menghindari perpecahan dalam menentukan awal bulan Qamariyah.

Melihat realita di negara Indonesia, bahwa terkadang ormas-ormas Islam pernah berselisih (berbeda pendapat) dengan pemerintah ataupun sesama ormas Islam yang lain dalam menentukan awal bulan Qamariyah. Sesungguhnya, ketika melihat substansi dan tujuan dari qaul di atas, pada zaman dahulu ormas-ormas (mazhab-mazhab) Islam nampak tidak menonjolkan keegoisannya dalam persoalan penetapan awal bulan Qamariyah, mereka lebih mengedepankan persatuan dan kesatuan umat. Mengacu kepada realita di Indonesia, ketika ada ormas Islam yang berbeda penetapan awal bulan dengan pemerintah, menurut mazhab Imam Syafi'i diperbolehkan. Namun dengan catatan, ketika berpuasa dan berbuka harus secara sembunyi-sembunyi demi menjaga persatuan umat.

Namun pada zaman modern ini, dengan perkembangan teknologi yang canggih. Dapat dipastikan kabar tentang perbedaan penetapan awal bulan Qamariah dapat tersebar dengan cepat. Maka hal yang sesungguhnya harus dirahasiakan dapat tersebar dengan cepat. Untuk menghindari hal yang demikian, hendaknya setiap ormas Islam tidak mendahului penetapan pemerintah dalam menetapkan awal bulan Qamariah.
Melihat pembahasan di atas, penulis berkesimpulan bahwa tetap saja pemerintah mempunyai kekuatan dan otoritas dalam penetapan (itsbât) awal bulan. Adapun ormas Islam, organisasi ataupun perorangan hanya sekedar ikhbâr tentang awal bulan Qamariyah. Keputusan pemerintah tersebut, mengikat kepada mereka (masyarakat awam) yang tidak mempunyai kapasitas dan kapabilitas dalam menentukan awal bulan Qamariyah. Maka mereka wajib untuk mengikuti pendapat pemerintah (kementerian agama). Disatu sisi, ada hak ikhbâr bagi organisasi ataupun ormas-ormas Islam yang mempunyai kemampuan ijitihad dan seperangkatnya untuk melakukan observasi atau pengamatan awal bulan untuk mengumumkan awal bulan Qamariyah. Namun sekali-kali tidak boleh mendahului dari itsbât pemerintah yang pada hakikatnya mempunyai otoritas untuk hal tersebut.

\section{Kesimpulan}

Dari hasil kajian penelitian, diperoleh kesimpulan sebagaimana berikut: Pertama, Bahwa pada dasarnya pemerintah mempunyai otoritas untuk menetapkan (itsbât) awal bulan Qamariyah. Hal ini setelah melakukan analisis beberapa aspek, diantaranya aspek pemerintahannya kemudian ruang lingkup aplikasi pendapat pemerintah, mekanisme dan keputusan pemerintah mengenai awal bulan. Oleh karena itu, pada dasarnya pemerintah mempunyai otoritas untuk menetapkan awal bulan Qamariyah.

Kedua, Melihat bahwa persoalan penetapan awal bulan merupakan ranah ijitihâdî, maka wajar terjadi perbedaan pendapat. Namun ketika persoalan tersebut sudah diadopsi dan ditetapkan oleh pemerintah maka menurut Qardhawi harus tetap mengikuti pemerintah. Karena pemerintah mempunyai otoritas dalam menetapkan awal bulan Qamariyah. Organisasi-organisasi diluar pemerintah hanya sekedar mempunyai hak ikhbâr, meskipun demikian hendaknya organisasi-organisasi tersebut tidak boleh mendahului penetapan pemerintah. Bagi umat muslim yang tidak mempunyai kemampuan ijtihad di dalam menetukan awal bulan Qamariyah wajib mengikut kepada pemerintah dalam penetapan awal bulan Qamariyah. 


\section{DAFTAR PUSTAKA}

Abdul Khaliq, Farid, Fî Al-Fiqh Al-Siyâsy Al-Isâmy Mabâdi' Dusturiyyah Al-Syûra Al-'adl AlMusâwâh, diterjemahkan oleh Fathurrahman A. Hamid, Fikih Politik Islam, Jakarta: Amzah, 2005.

Abdul Mu'id, "Kontroversi Dzulhijjah 1428 H Saudi Arabia”, http://teknologi.kompasiana.com/ terapan/2011/09/15/kontroversi-dzulhijjah1428-h-saudi-arabia/. Diakses pada tanggal 16 Desember 2011

Abu Yusuf, Ahmad Sabiq bin Abdul Lathif, Bid'ahkah Ilmu Hisab?! Kajian tentang Ilmiah Tentang polemik Hisab Rukyah Untuk Menetapkan Puasa Ramadhan dan Hari Raya, Gresik: Pustaka Fuqon, 2011.

Abu Zahrah, Muhammad, Ushul al-Fiqh, Mishr: Dar al-Fikr, 1958

Ahmad Sanusi, Tata Laksana Kegiatan Rukyat Hilal Awal Bulan Hijriyah Di Pob Palabuhanratu, http://www.pa-cibadak.go.id/artikel/baca/17, diakses pada tanggal 26 Februari 2012

Al-'Anbary, Khalid Bin Ali Bin Muhammad, Sistem Politik Islam, Menurut al-Qur'an, sunnah \& pendapat Ulama Salaf, Kuala Lumpur, Telaga Biru, 2008.

Al-Suyuthi, Abdul al-Rahman bin Abî Bakr, alAsbah wa al-Nadhair, Juz I cet. I, Dar Kutub al-Alamiah, 1983.

Al-Suyuthi, Abdul al-Rahman bin Abî Bakr, alAsbah wa al-Nadhair, Juz I cet. I, Dar Kutub al-Alamiah, 1983.

Al-Thirmidzi, Muhammad bin 'Isa Abû 'Isa, Al-Jâmi' Al-Shohih sunan al-Thirmidzi, Juz 4, Beirut: Dâr Ihya al-Turats al-'Arabi.

Al-Thirmidzi, Muhammad bin 'Isa Abû 'Isa, Al-Jâmi' Al-Shohih sunan al-Thirmidzi, Juz 4, Beirut: Dâr Ihya al-Turats al-'Arabi.

Departemen agama RI, Alamanak Hisab Rukyat, Jakarta: Proyek Pembinaan Badan Peradilan Agama Islam, 1981.

Djamaludin, Thomas, Astronomi memberi Solusi penyatuan Umat, Lembaga Penerbangan dan Antariksa Nasional: 2001.

Djazuli, Ahmad, Fiqh Siyâsah (Implementasi Kemaslahatan Umat dalam Rambu-rambu Syariah), Jakarta: Kencana, 2003.

Ensiklopedi Hukum Islam, Jilid 2, Jakarta: PT Ichtiar
Baru Van Hoeve, 2003.

Hamzah Syihabuddin, Syamsuddin Muhammad bin Abi 'Abbas Ahmad, Nihayâh al-Muhtaj Ilâ alSyarh al-Minhaj, Juz 25 Hal 381, CD Maktabah Syamila II

Izzudin, Ahmad, Fiqh Hisab Rukyah Menyatukan NU dan Muhammadiyah dalam Menetukan Awal Ramadhan, Idul Fitri, dan Idul Adha, Jakarta: Erlangga, 2007.

Mahfud M.D, Moh, Politik Hukum Indonesia, Edisi Revisi, Jakarta: PT Raja Grafindo, 2010

Muhammad bin Abdul Wahid, Kamaluddin, Syarah Fath al-Qadîr, Juz VI, Hal 99, CD Maktabah Syamila II

Mun'im Salim, Abdul, Fiqh Siyâsah Konsepsi Kekuasaan Politik Dalam Al-Qur'an, Jakarta; PT Raja Grafindo Persada, 1994.

Murtadho, Ilmu Falak Praktis, Malang: UIN Press, 2008.

Murtadho, Imkan ar-Rukyat Dalam Penetuan awal Bulan Qamariyah: Perspektif Syariah dan Astronomi Manhaj Nahdlatul Ulama, El-Qisth Jurnal Hukum, 2007.

Musbikin, Imam, Qawa'id Al-Fiqhiyyah, Jakarta: PT Raja Grafindo Persada, 2001.

Ni'am, Asrorun, Idul Fitri Mazhab Negara, http:// www.mui.or.id/ diakses pada tanggal 16 November 2011.

Proyek Pembinaan Administrasi Hukum Dan Peradilan Agama, Pedoman Awal Bulan Qamariyah, Jakarta: Proyek Pembinaan Administrasi Hukum dan Peradilan, 1983.

Qardhawi, Yusuf, Min al-Fiqh al-Daulah Fî alIslam, diterjemahkan oleh Khatur Suhardi, Fiqh Daulah Dalam Perspektif al-Qur'an dan Assunnah, Cet. I, Pustaka al-Kausar, 1997.

Qardhawi, Yusuf, Min al-Fiqh al-Daulah fi alIslam, makantuha, ma'alimuha, thabi'atuhu, manqifatuha ad-dimaqratiyah wa atTa'addudiyah wal-Maar'ah wa Khairul muslimîn, diterjemahkan oleh Syafril Halim dengan Judul, Fikih Negara, Jakarta: Rabbani Perss, 1997.

Qardhawi, Yusuf,Al-Siyâsat Al-Syar'iyah, diterjemahkan oleh Khatur Suhardi, Pedoman Bernegara Dalam Perspektif Islam, Cet: 1, Jakarta: Pustaka Kaustar: 1999. 
Qardhawi, Yusuf, Malâmih al-Mujtma' Al-Muslim Aladzi Nunsyiduhu, diterjemahkan oleh Abdus Salam Masykur, "Mayarakat Berbasis Syariat Islam Akidah, Ibadah, akhlak, Solo: Era Intermedia, 2003.

Rasyid Ridho, Muhammad, Al-Manâr, Juz 5, Hal, 160, Diambil dari Maktabah Syamila

Sudirman, "Yusuf Qardhawi: Pembaharu Fikih Islam Kontemporer", El Qisth, Jurnal Ilmiah Fakultas Syari'ah, Fakultas Syari'ah UIN Malang: 2005.

Syafi'I, Imam, Al-umm, diterjemahkan oleh Abu Abdullah Muhammad Idris, Ringkasan Kitab al-Umm, Jakarta: Pustaka Azam, 2006.
Thomas Djamaluddin, "Renungan Tahun Baru 1914 H: Pelajaran Tiga Hari Raya", http:// tdjamaluddin.wordpress.com/2010/06/15/ renungan-tahun-baru-1419-h-pelajaran-tigahari-raya/, diakses pada tanggal 16 Desember 2011

Thoriquddin, Muhammad, Relasi Agama Dan Negara, Malang: UIN-Malang Press, 2009.

Triwulan Tutik, Titik, Konstruksi Hukum Tata Negara Indonesia Pasca Amandemen UUD 1945, Jakarta: Kencana, 2010. 